\title{
SB
}

235

\section{THE SORGHUM SUGAR INDUSTRY.}

\section{DEPARTMENT OF AGRICULTURE.} SPECIAL REPORT-No. 54.

\section{ADDRESS}

OF TIIE

\section{HON. GEO. B. LORING}

U. S. COMMISSIONER OF AGRICULTURE,

BEFORE THE

Mississippi Valley Cane-Growerss Association,

$$
\text { ST. LOUIS, MO., }
$$

DECEMBER 14, 1882.

WASHINGTON:

GOVERNMENT PRINTING OFFICE.

1883. 


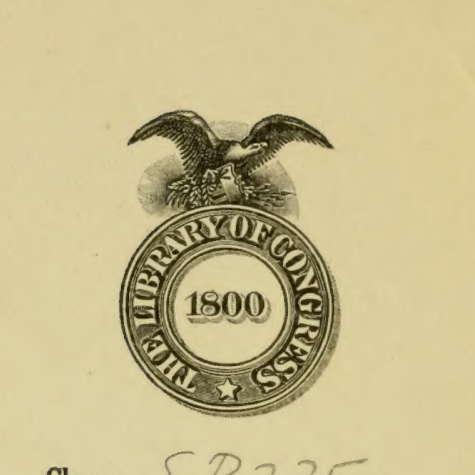









\title{
THE SORGHUM SUGAR INDUSTRY.
}

\section{IS. DEPARTMENT OF AGRICULTURE.}

SPECIAL REPORT-No. 54.

ADDRESS

OF THE

\section{HON. GEO. B. LORING}

U. S. COMMISSIONER OF AGRICULTURE,

BEFORE THE

Mississippi Valuey Cane-Growers Association,

\section{SAINT LOUIS, MO.,}

\author{
DECEMBER 14, 1882.
}

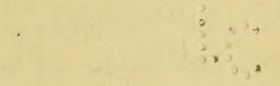

WASHINGTON:

GOVERNMENT PRINTING OFFICE. 


$$
53^{23^{5}}+81
$$




\section{A D D RESS.}

Genthemen : The foundation and development of a new industry in this country is entitled to all the respect and admiration which are won by great achievements on more prominent and couspicuous fields of aetion and thought. The record of military enslearor, by which we have fommerl and preserver our nationality; the history of the intense civil struggle out of which sprang our Federal Constitution; the brilliant years in which are recorded the efforts of the dmerican mind to secure a foremost place in the bright realms of science and literature, will always challenge the wamuest consideration of all thoughtful men. But the growth of our varied industries constitutes a chapter from which no student of man's progress can turn indifferently away. Standing as we now do in the midst of fertile aud cultivated lands, whose annual product has reached the enormous sum of $\$ 9,000,000,000$, we turu with profombl respect to him whose axe struck the first blow in the primitive forest, and whose hand first planted the treasured seed for a scanty harvest in a virgin soil. TWe are never weary of the recital of the first feeble but determined efforts of Sammel Slater to establish cottou manufictures in this conntry, now nearly a century ago, or of the far-reaching courage and foresight which, twenty years later, led Lowell, and Appleton, and Jackson to contemplate from the snowy banks of the Merrimac the porer of that rushing river, confirdut that a great industrial city would be fommled there whose looms would clothe the rorld, and establishiug a national enterprise with a capital of $\$ 250,000,000$, employing nearly 200,00(0) per'sons, consuming nearly 1,000,000,000 pounds of raw cotton, and ruming more than $10,000,000$ spindles. 'The early endeavors of our father's to establish the woolen industry, with their little flocks and their houselold loóns, an industry now employins it catpital of $\$ 150,000,000$, producing goods valued at $\$ 250,000,000$ ammally, cousmming ?00,000,000 pounds of wool, and employing more than 100,000 persous, are as fasconating as the fables of antipuity. We turn back from the enormons shoe and leather interests of our day, and contemplate with a natural incredulity the early labor's of those who tammed a few domestic hides in domestic tan-vats, and manufactned slowly the rulle and enduring shoes of the family by the fireside. Mro are lost in womler before the seven and a half millions of tons of iron and steel produced in this comntry last rear, and recall with still ereater wonder the faret that within the lifetime of many a man amone ?ts this grat industry was fombled as a national entreprise. And as 
we survey this vast fichl, we are always impressed with the cvidences written there of the wise and well-directed enthusiasm, the deliberate judgment, the keen foresight, the mwavering eomage, and the power of dispassionate investigation, which man has exerciserl in laying the foumbation of the best forms of state and society an prosperous and well-educated industry.

It is in this honorable service that those. who wonld develop a new somce of wealth in our day are engaged, and whose efforts entitle them to all the light which seience can bestow, all the encouragement which public spirit can give, and all the direction which somnd, unbiased, prar. tical wistom can apply. I)iscoveries and inventions are made by investigator's patiently pursuing their mobtrusive way, with minds and hearts superior to all natural obstacles and free from prejulice or passion. And so we approach the examination of every question in which mans welfare is involved, with an ardent desire to discover the truth and a natural inclination to lend all the aid in our power to the solution. Im. pelled by this desire and guided by this inclination, I have arecepted your invitation to address you on this oceasion, and to explore with you the industry to which you are rlevoted. I camnot expect to teach you the alt of maunfacturing sugar from any of the sugar-producing plants. But I have watchel with great interest, both as a citizen believing in prosperous industry, and recently as an oflicial engaged in encouraging the producing classes, all the efforts which have been made to perfect the work for which this association is organized. If I repeat what you already know, you will pardon me, and receive my assurance that I am desirous of incuiring into and adrancing your industry by your own practical means and in your own practical spirit. My last oflicial ap. peal for information was made to the manufacturers themselves who are engaged in establishing a profitable business and not in defenrling a theory.

The history of the sorghum industry in this (onmtry is rurious and interesting, and familiar to your all. Trenty-five rears ago or more 1 planterl it on my fanm in Essex County, Massaldusetts, as a green tonage colop for my mileh rows. But at that time my attention was called to the plant as andapted to the production of sirmp and sugar, and I studienl with interest the essays of 1). I. Hown, and the opinions of

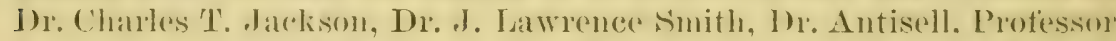
Goessmamm later, all declandug that the sugar contained in sorghum is crystallizathe, but differine in their views as to the methorl by which

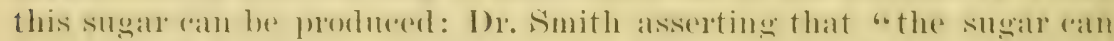
he obtained by processes analogons to those emploged lor extracting

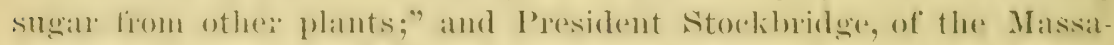

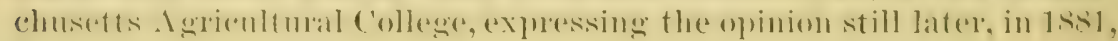
that-

The experiments with sorghum, as a suerar-producing plant, forever settled the fact that no known variety of it can bo protitably employed for the purpose, unless chemieal seience cau diseover a law by which gheose cau be changed for cano sugar. 
During this long period of time in which the possibility of producing sugar from sorghum was discusserl and experimented upon, the production of molasses had largely inereased, and during the war many sections of the country depended npon sorghum almost entirely for their supply of this important commodity. Meauwhile an interesting discussion arose with regard to the time for harvesting the sorghum, and the condition of the seed at which the largest amomt of sugar could be obtained. In. Jackson found that "the juice from stalks with quite ripe seerl was by far the sweetest, while the green one which was just in flower containel lout very little saccharine matter:" Vilmorin thought that sugar conld be "easily obtained in all eases where the came can be sufficiently ripened." Dx. Jackson also says: "The umipe canes can be employed for making molasses and alcohol, but, as before stated, will not yield true cune sugar." Dr. J. N. Suith, of Quincy, Ill, in 186", says: "The sirup from sorghum will not make sugar if the eane is ent before the seed is in the dough." Mr. Bollman, of Iowa, adrocates "perfect maturity." William Clough, of Cincinnati, Ohio, in 1864, declared that the precise perion most appropurate for harresting the cane is "when the seerl at the midllle of the panicle is just beginning to harden or pass from the fluid or milly state." On the other hand, Professor Emi, in 1865, stated that "the juice from mripe cane readily erystallized." In 1866, the "Sorgho Mantfineturers" Ianual" stated that "the cane is in the best state for harvesting when part of the seed is beginning to turn black, or in other words, when the seed is in the doughy state." In $186 i$, a eorrespondent of the Department of Agriculture, says: "I take the sorghnum when just fairly in bloom. In no case do I allow the seed to mature when I wish to make sugar, but for No. 1 sirup I let the cane mature." In $1869, \mathrm{Mr}$. Wm. Clough, editor of "The Sorgho Journal," says: "I Do not minc the panicle if the juice has a clear sweet taste; even if the panicle is only in bloom, cut and work the cane." Again, in February, 1869, page 92, in an article entitled "Immature cane best for sugar," he says: "The theory that cane should be harrested before fully ripe, when designed for sugar, has been further confirmed by the experience of this year. The other ilea, that the eane should be fully ripe, was never confirmed by facts." Page 58 it says: "The weight of eridence just now is in faror of cutting as the seed is passing from the milk to the dough state." In $1873 \mathrm{Mr}$. E. IV. Slimmer, of Sioux City, Ioma, says, in the ammual report of the Department of Agriculture: "The best sirmp is malle from came not fully ripened." In 1s.0, the "Sorgho Ifand-hook," published by the Blymyer Manufacturing Company, Cincinnati, Ohio, stated that "The eane should be "ut when the seed is in the dongh." In 1881, Professors Weber and scoville, of the Illiuois Industrial Ciniversity, rays: "The propere time to begin cutting the "ane is when the seed is in the hardening dough."

Opinions have differed also with regard to the best time fin working 
the canc after it is cut. Dr. Smith, in his report to the Department of Agrienlture in 15\%7, says: "The uncrystallizable sugar forms rajoilly after the cane is fully ripe and recently cut." IIence, it is evirlent that no time is to be lost after entting in expressing the juice. I)r. Cook, in the anmul report of the Ohio department of agriculture in 1861 , thinks the cane should he allowed to "season a few rlats" after heing ent. Mr. F. A. Merlges, in the Ammual lieport of the l)epartment of A griculture for 1s61, says: "After the canes have been topped, stripred, ent up and tied in bumlles, they may be set up in the open air or, prefer-

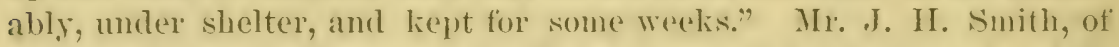
Quincy, Ill., in the lieport of the Department of A griculture for lstid, says: "The caue should be brought to the mill and cousherl on the same day." Mr. William Clough, in the Anmual Report of the Bepart. ment of A griculture for 1865 , says: "It would be best to allow but little time between havesting and working the cane; and on no areonnt should it be stored and allowed to remain long in large shocks." The Sorgho Manufacturel's" Manual, in 1866, states that "the cane should be cut and shocked in the fiell, with tops on; and in this condition it may remain sereral months before being worked up, for the cane watures and forms mole sacelarine matter." Professors Wreber and Scoville, in their report of $18 \$ 1$, Illinois Industrial Tuiversity, say: "The cane should be worked up as soon as posibible after cutting."

In the midst of this conflict of opinion the investigation of the sorghum cane as a sugar-producing plant was undertaken loy the Department of Agriculture in 157s, and has been continued to the present time. Elaborate scientific analyses have been made sear after year in the laboratory, and an attempt has been made to manufacture sugar in a mill erected on the giomuls of the department from sorghmm grown on lands lying in and around $W^{T}$ ashington. The results of these operat. tions I desire to submit to your eonsideration, believing as I do that the test of all economic science lies in the hand of the producer, and that this association of practical sorghum growers and sugar manmfactures is the jury before which every experiment is to be tried for a verdict.

I submit the comelnsions alrearly arrived at by the elemist of the department as latid before me. He informs me that "the following conclusions may be faily claimol as having beran estahlishor by the experiments" made in the department:

1. The presence in the juices of several varieties of maize of an amomnt of sugar greater than is foume nyon the average in the juices of the sugar loets grown in the Lnited states and analyzed by this depart ment.

2. The presenere in the juites of sereral varieties of sorehtum of an amount of sugar esual to that present in the arerage juice of the sugar cane of Louisiana.

3. The pessihility of recorering in the sirups as large a pereentage of 
the sugar present in the juices of maize and sorghum as is recovered from the sugar-cane juice, and by processes and appliances identical with those employed in the production of sirups from sugar cane.

t. The number of days from planting when these several varieties of sorghtm have attained approximately their maximum contents of sugar, from 92 to 139 days.

万. The number of days during which these several rarieties retain : pploximately their maximum content of sugar and may be most profitably worked up from 92 to 122 rlays.

6. That the increase in sngar during the later period of development in the plant is not caused by a drying up of the plant.

7. That in this latitude, during ordinary seasons, there wonld bo at jeriou of three months' duration in which one variety or another of sorghum would contain its maximum content of sugar and could be most profitably worked therefor.

s. That the so-called gum which often causes tronble in the purging of the sugar from sorghum is not present in the juice of the plant, but is a product of manufacture, and is often present in but small quantity; and its formation, therefore, mas probably be entirely prevented by finther investigation.

9. That sorghum and maize, after being ent up, are in great danger of having the sugar present in the plant inverted, and that therefore the only safe way is to work up the cane within a few hours at most after cutting.

10. That for the purpose of sugar production, immature cane is worse than worthless, and should therefore be carefully kept apart from such cane as is intended for the production of sugar, and should be worked up only for sirup. (Yonsequently a miform stand of cane should be secured at the first plantiug, and such rarieties of the sorghum are to be preferred as do not have a tendeney to throw up suckers.

11. That the result of a heary rainfall, even after a prolongee? drought, did not effect the guantity of juice nor increase the water in the sorghums.

12. That the effects of frost depeuded entirely upon the condition of maturity of the sorghum, being in one case disatstrous and in another without apparent effect.

13. That the juice after defecition conld be kept over night before being evaporated to sirup withont suffering any inversion of the sugar present.

14. That water condd be added to the juiee during defecation withont cansing any loss of sugar.

15. That the specific gravity of the juice fumishes a conrenient means by whieh the amount of sugar may be determined.

16. That the results obtained by analysis were in very dose agreement with those obtained by the polariscope.

17. That the excessive dronght cansed an inerease in the sugin of the 


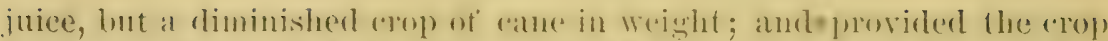
has secured a good start, it is capalole of sustaining severe drought, but unless a georl stant is secured, the efferet of the drought is disastrous.

18. That an excess of lime in defecation bats the effect to destroy glucose and darken the sirmp proiluced, but did not affect the suerose present.

19. That the seed of the sorghlums is about ielentical! in composition with maize and probably of equal nutritive value.

In addition to the points thus determined in the opinion of the elemeist, I learn from him that he experets to ascertain from the analyous now going on at the Departiment-

1. The alsolue and wative value of new vallecties als complated with rarieties examined in past years.

2. Proximate composition of juices of sorghum.

3. Loss of sugar in begasse.

4. Effect of stripping.

These are the points which have been and will be latil down by the chemist of the Agricultural Department for the benefit of those who are eugaged in the industry, hoth as farmer's and mamuficturers.

At the rerguest of the chemist of the department, I ealled "pm the Sational Acarlemy of sciences, on Jannary 30, 185"), to investigate the processes by which these conchusions had heen reathed in enformity with the act of Congress incorporating that borly. The report of at committee appointerl to make the investigation was submitted to me in May following, was withdrawn by the president and secretary of the Acarlemy for revision and "such action as the Acarlemy might deem necessary." (On the 15th of Sorember last the report was returned to me essentially

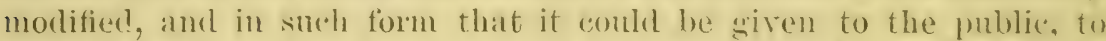
the satisfatetion of the Acarlemy and the instruction of the community. An alstratet was at once prepared and publisher hy the daily press: and the entire doement, which is clathorate and roluminons, will soon he issued in suecial form lyy the Agrioultural department. I regret that its completion by the Acardemy was so long delayed, and that its magnitule will prevent an anlier publication, even while l congrat. ulate you that the de lay fimmished an opportunity for the committer to secure valuahle information of the work done during the season of 1 s.', and, to lay before the conntry the latest knowledge of the pract ieat mam-

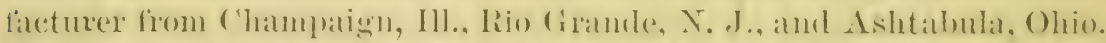
I am happy, however, to be able to lay lefore you what the deatemy

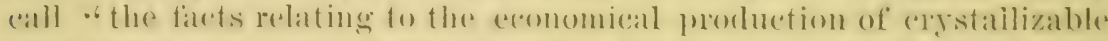

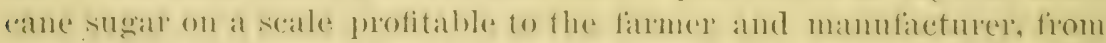

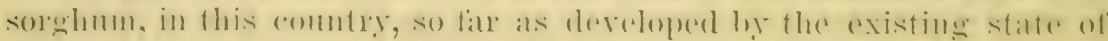
the laboratory and field practice."

1. That these plants develop at maturity, and when the seed is ripe a maximum of cane sugat and a minimum of grlneose.

$\therefore$ 'That the maximum of eane sugrar in soryhnin juices is found associated with about one-tenth its weight of erape sugar (glucose), and not far from one-fifth its weight of solids not sugar, vi\%: atsh, grum, chlorophyll, albumen, wax, aconitic acid, \&e. 
3. That after maturity the relative amounts and proportions of the chiof fictors rary but little, even for a period of three months or more, provided tho season does not change; e. $g$., an early maturing variety of sorghum holds its own until frost; i later variety has a shorter working period.

4. That while varieties of sorghum differ greatly in rapidity of growth and time of reaching maturity, in size, weight, and consequent yield per acre, it appears that all varieties of sorghum resemble each other in developing at maturity, under the same couditions, nearly the same naximum percentages of cano sugar, glucoso and solids, the cane-sugar maxima varying from 14 to 16 per cent. of the total weight of the expressed juice, the other factors being as stated under 2 .

5. The soil best alapted to the growth of a grool crop of sorghum for sugar appears to be a sandy loam. 'This plant thrives on soils and in elimates too light aud dry for maize, and makes the best "stand" when grown closer than Indian cor"n admits, in a given Jocality.

6. While good sirup may be produced from sorghum, as a domestic industry, and on a limited scale, over a very wirle range of country, the successful production of crystallized sugar on a commereial scale, appears to demand the skill and a ppliances of a sugar-house conducted in a systematic maner and with ample capital.

7. The best results in sugar are obtained ouly when the ripe eane is manufactured on the same day in which it is cut from the field.

8. The seed of ripe sorghum is a valuable feed crop, equal, for fattening animals, to maize, and in product is equal from $2 \frac{1}{2}$ to 4 bushels per ton of eane.

9. About forty per cent. of the juice of sorghnm is lost in the begasse, as it is, to nearly the same extent in tropical sugar cane; more than one-half of which loss may probably be saved to the crop by process of displacement yet to be perfected.

10. Of other residual products, the seum ant sediment, rich in various elements of fertility, are now thrown away. The begasse, when treated by a pulping machine, gives a valuable paper stock. Treated as a fertilizer, the begasse will return to the soil a portion of what the plant has borrowed from it in its growth. In regions where fuel is dear, the begasse can be used with adrautage as finel.

I thiuk many of these conchusions can be properly and protitably diseussed by this conrention.

Having laid before you the points which have been developed hy the seientific work of the Agricultural Department, I will now call your attention to the effort made by the department to manufacture sugar, and to point out the way by which sorghum could be raised as an agricultural crop, and by which it could he converted into sugar as a manufacturing industry.

In my report to the President, November "25, 15s1, I made the following statement:

Congress at its last session appropriated the sum of $\$ 25,000$ for expenses of machinery, apparatus, labor, \&c., to continue experiments in the mannfacture of sugar from sorghm and other sugar-produciug plants, the appopriat ion to be immediately available. My predecessor had purchased the machinery and apparatus, appointed several additional chemists, and made contracts with parties residing near this eity to raise sorghum cane for experiment. Upou assuming the duties of my oftice, I found growing 135 acres of sorghum, consisting of 52 varieties. Having engaged the services of an expert in sugar-making who was highly recommended for the position, operations were commeneed at the mill on September 26 and continued with slight interruptions until the latter part of October, at which time the supply of eane became exhansted. Forty-two acres of the sorghum were orertakeu by frost before being sufficiently ripe for use, and the erop was so badly damaged as to be regarded unfit for experiment. 
'The following condensed statement gives the results of the operations for the saran :

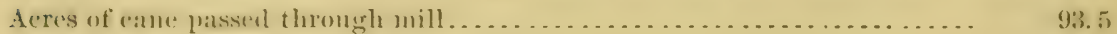

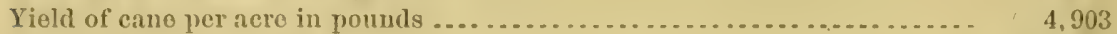

Pounds of cane erushed . . . . . . . . . . . . . . . . . . . . . . . . . . . . . . . . . . . . . 458,444

Gallons of juice obtained after defecation........................ 2. 26, 794

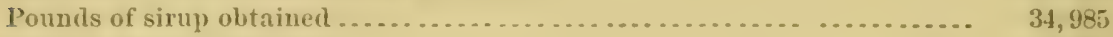

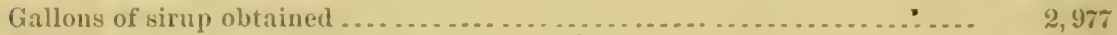

Pounds of sugar obtained . . . . . . . . . . . . . . . . . . . . . . . . . . . .

The expenses of raising the cane were as follows:

Rent of laud

$\$ 1,85400$

Labor and superintendence .................................. 3, 474 292

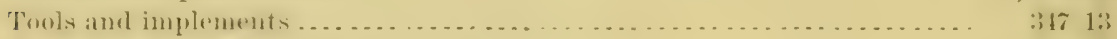

Hire of teams and hauling of caue to mill . . . . . . . . . . . . . . . . . . . . . . . 91410

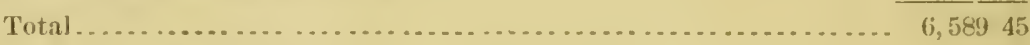

Expense of converting the cane into sirup and sugar.

For labor and running mill .................................... $\$ 1,34211$

Coal and wont ............................................ 32548

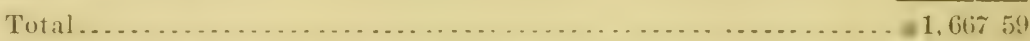

The cost of 2.97 gallons of sirup and 16 i pounds of sugar was $\$ 9,25 \% .04$, not counting the wear and tear of the manhinely, or the interest on the outlay for the mill.

The crops brought to this mill were raised by Mr. S. M. Golden, I)r. Dean, each on his own land, and hy Mr. Culver, on land hired of Mr. Carlisle Patterson.

Mr. Golden's land was in good tilth, had been previously cultirated, and was a warm somewhat light loam of clay and samd intermixel. He states to me that he planted 28 acres, as follows: (i acres planted 11 ay 4-6; 2:3 acres planted May 7 ; 7 a areses planted May $8-10$; 12 acres planted May 17-2S.

The 12 acres were of the Ifonduras variety, and the remainder eonsisted of 51 different varieties. He says he was continually replanting and filling in the rows, until about enme 15. At that time, motwithstand. ing all his efforts, at least if of the lamel had nostame. The department paid him a rent, stente per acre for the land for the seasom, and for all

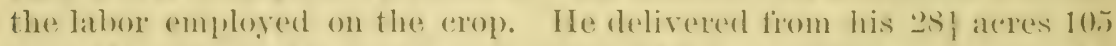

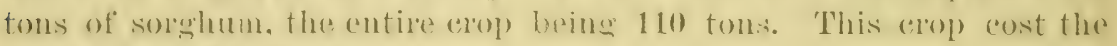
government $\$ 1,367.25$.

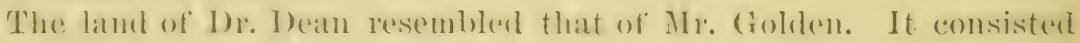

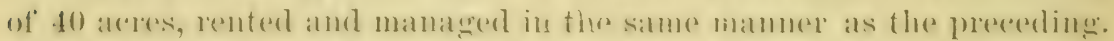

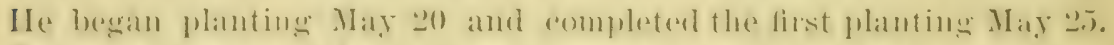

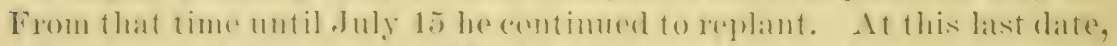

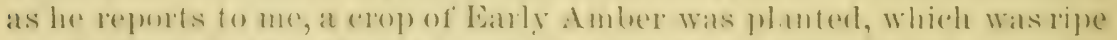

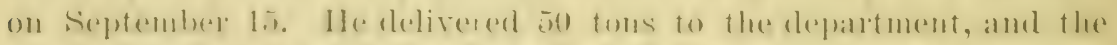

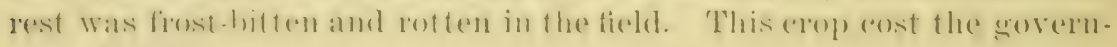
ment $\$ 2,000$. 
The land renteri of Mr. Carlisle Patterson, consisting of about 65 acres, was divided into two lots, according to the statement of $\mathrm{Mr}$. Culver who had eharge of it, one of which was planted with Early Amber, and the other with "Link's Hybricl." On Tuestay, May 10, the planting of this land commencerl, and the work was renewed until June 18, when it was planted for the third time. The land was a pastnre which had been heavily fed for years, and was plowed just before planting. Yon will not be surprised to learn from Mr. Culver that the first "lot of seer was nearly all destroyed by worms" on land like this, and that the worms continted their ravages until they were driven away by rolling the seed in coal-tar. The amount of cane delivered to the department from this land was about 100 tons. The cost of this crop to the government was about $\$ t, 000$. No manure or fertilizer of any lind was used on these parcels of land, either on the worn-ont pasture which was filled with wire-worms, or on the old land which had been previously cropped. The land of Mr. Patterson was a light sandy loam.

This agricultural operation shonid be serionsly considered. Mrs. Glass in her famous English receipt for cooking a have commenced by saying, "First catch your hare." To those interested in the sorghum industry, whether on the land or in the mill, the foremost injunction is "First get your crop," by the exercise of all that wisdom in the selection of land, and the modes of fertilizing if necessary, and the care of the crop, which enables the farmer to raise the great corn crop of the West, and the valuable special crops of the East. On the ninety-three acres harvested, the yield was about two and a half tons to the acre. The yield of sirup and sugar from this was small. The result in the large mill and in a a smaller one deroted to special processes was very unsatisfactory. I should say the lesson learned from all this was what to avoid and not what to follow. 'To the farmers it gave so poor encouragement, that when I endearored to employ them to raise a crop for the work of the jresent season, one of them experieuced in the efforts of last year proposed to raise it for me at $\$ 15$ per ton, and an inexperienced one proposed to raise it for $\$ 6$, and finally concluded that he had better not raise it at all. At this stage of the proceedings, haring satisfied myself that the experience of practical men endearoring to work to a profit, was expecially necessary for the development of the industry, and that a judicious selection of locality is necessary for this as for erery other industry, I called upon the manufacturers throughout the conntry to contribute the results of their experience duing the present year. To a circular issued by me in June last, calling upon them to furnish me information upon their valions modes of manufacture and the results, I have reecived nearly a hundred responses, and I feel confident that much valuable knowledge will be compiled from these communieations.

I have also secured from other sonces accounts of work now going on, which I feel confident will be interesting to this association.

In the report of the Acarlemy of Sciences to which I have alhuded, I 
find many references and oppinoms with which you are all fimilian; and 1 also find (alborate stitements of work performerl during this last smmmer amb antumm to which I rall yom attention, as the most recent information we have upon this subject.

'The committere having in the first haft of their report presented the

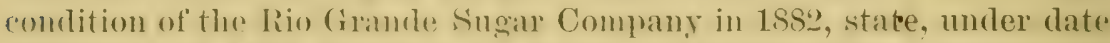
of October 12, 1 s.: , that they are able to ald the following information obtained by a personal examination of the plantation and sugar works of this establishment. They say:

This eompany (the Rio Grande Sugar Company, Cape May Comnty, New Jersey, ) aro the present owners of their works, and also of 2,401 aceres of land, chicfly of a light and not fertilesoil, lering on the peninsular betwen Dela ware Bay and the sea, within five or six miles of (alpe May and is miles sonth of Pluilatelphia. April 19, 180.0, aud following, they put in, of Amber cane, 958 acres; Linke's Hybrid, 25 acres; Larly Orange, 23 acres; and Honduras, 2 acres; in all, 1,008 acres. Warned by former experience the company determined to own and cultivate its own cane. The very cold and wet spring oceasioned the lows of at considerable portion of the first planting. the loss being also due in part to deep planting by unskillful hands. The deficient portions were replanted in June, leaving such portiuns of the first planting as came up to grow together with the secoud planting. This circumstance worked considerably to the injury of such portions of the crop, and reduced the exponent of sugar notably. Notwithstanding this untoward circumstance the clop, as we first saw it, near the close of September, presented a noble appearance of vast fields of luxuriant cane ready for the rolls, and still full of vigor and of a deep green color. The Amber cane stood about 8 to 10 feet in height; the Orange and Linke's Hybrid were higher, being from 12 to 14 feet. The Amber cane only was ripe at that time, and the harvesting liad leeen in progress from the 2 - th of Angust, at the rate of 120 to 150 tons of the wane delivered daily to the mill, which is the present limit of the floors to accommodate the sugar wagons. 'The mill is a powerful apparatus of three rolls, each 5 feet long and 30 inches in diameter, driven by a steam-engine of 125 horse-power, crushing the caue with an opening of ouly one-sixteenth of an inch between the rolls. The stalks are not stripped, only the dead heads are removed in the field. This mill is capablo of crushing 300 tons or more daily, hut the floor space of the works limits the outpost, as before stated. 'The product of sugar exceels the most sanguine expectations of the projectors.

The Amber eane, on a large area, stands not less than 10 tons to the acre on about z00 acres. The exact figures for the whole crop can be given ouly when the account is fully made up. Each day's cutting is accurately recordecl, and so can now bo safely stated. We saw the "strike" of" the vacuum-pan of 1,600 gallons on the 28 th of September, and again on the 11th of October, filling nime wagons of one ton capacity each with "męlada," yielding $2 \frac{1}{2}$ or 3 barrels of sirup to the ton. 'The yield of sugar to the wagon would be, by estimate, greater by about half a barrel (the barrel holds $355^{\circ}$ poumds) if moro time conld be allowed for it to stand before going to the centrifngals.

From the mill the green juice flows to a tank of 1,000 gallons capacity, whence it is pumped to defecators, after which it is hurred through tho open pans to the vacuumpan, where it is redneed to abont 320 B., and thence to the larger pan of 1,600 gallous, where it is raised to about $45^{\circ} \mathrm{B3}$, or a temperature of about $140 \mathrm{~F}$. 'There are two "strikes" of this pan daily. 'The lack of space for cooling compels, at preseut, the working of the melatia in the centrifugals, of which there are four, before it is completely cooled, so diminishing, as just stated, by probahly a half barrel, the yield of "firsts."

We examined the bookso Heny I. Inghes, the supreriitendent, who is a sugar boiler 
of twenty years' experience, which showed the juice of the daily workings, as tested by polariscope, to have a coefticient of from $10^{\circ}$ to $12^{\circ}$ for the new juice, which is polarized several times daily. For the week ending the day of our first risit 656 tons of cane were crushed, yielding 115 barrels of sugar of $83^{\circ}$, and 89 barrels of molasses of $47^{\circ}$. The first sugar was equal to 63 pounds to the tons of cane crusherl.

The fertilizers used on the land of this plantation this year were about 2is bushele of lime, followed by 150 pounds of Peruvian guano, having as much sulphate of ammonia added as raised the nutrogen to 8 feet. This guano cost $\$ 53$ per ton. A few acres wore treated as an experiment, with fair results, with barn-yard mamure; on about 20 acres fish guano alone was used, the effect of which was to rednce the available sugar by about $1^{\circ}$ on the polariscope. On the whole the lime, the guano, and stable manure gave good results. Greensand marl, which abounds in New Jersey, remains to be tested hereafter. The crushing of the cane with the leaves settles one of the "sor. ghum questions" on which there has been much difference of opinior. In practice, on a large scale, the removal of leaves would involve an impracticable amount of labor. In the 1879 Report of the Department of Agriculture, 1. 59, are experimental results showing an increase of both juice and sirup from the crushing of the entire plant (seed excepted). A small loss of available sugar and a gain of sirup will probalby result from crushing the blates with the stalks, a suljeet recpniring further examination. It is by no means improbable that in the plant's life the sucrose is elaborated. directly in the leaf, and is gradnally transferred to the stalk, where it accumulates.

The fall returns for the crop of this year will not be in before the closing of this report. But we are able to state from a communication of date Norember 8,1882 , from the president, that the probable results of the season's work ending November 11 are as follows: 6,000 tons of cane, 950 barrels of first sugir, and 1,100 barrels, 50 gallons each, of molasses. The seed is not yet measured, and a full balance sheet remains to be made up, which may, perhaps, come in season to be added to this report.

The Orange cane turns out rather better than the Amber, being richer in juice, and with an average test of $13^{\circ} \mathrm{B}$.

This committee have received from Mr. Knight, the sugar refiner of Philadelphia, a harrel of the sugar, sample of a lot of :350 barrels refined by him, of the Rio Grande Sugar Company. It ranks, on the independent judgment of experienced growers to whom we have shown it, as "C" sugar.

Analyses of the soils of different fields are now in progress to determine, if possible, the canses which inflneuce such very unlike productiveness as the experience of the season of 1882 has shown to exist-the difierences of yield being per acre: $3 \frac{1}{2}$ tons with guano and no lime; $5 \frac{1}{2}$ tons with guano and no lime $; \frac{1}{2}, 8,15,17$ tons respectively.

Since the completion of this report of the Academy, I have received the following statement with regard to the product of these works in 1882: sugar, 319,000 pounds; molasses, 40,000 gallons.

It will be observer that no reference is made in the report to the methods employed in the manufacture of the sugatr. It is to be presumed, therefore, that they are such as are usually employed in the production of cane-sugar.

The committee of the Academy have also laid before me an interesting. statement of the work of the "Champaign Sngar and Manufacturing Company," Champaigu, Ill., as follows:

The undersigned have the honor to present to you the following report on the manufacture of sorghum sugar for the year 1882. Our report is necessarily incomplete, as we are still in the midst of our season's work; but the gratifying results thus far obtained will, we hope, warrant our reporting the data on hand.

HENRY A. WEBER. MELVILLE A. SCOVELL.

Cifamparge, Ill., October 28, 188?. 
As a result of the experiments carried on hy the writers in the seasons of 1800 and $18 \$ 1$, the C'hampaign Sugar Company of Champaign, Ill, was organizerl. The object of the company was to carry out, on a commercial scale, the production of sugar from sorghum, as was indieated by the laboratory experiments. The company was organized with a eapital stock of 825,000 . The total expenditure for building the works and raising the crop, however, was more than $\$ 30,000$. The main building is 40 by bif feet, and there stories high, with a lean-to, 4.5 hy 30 fieet, covering the engines and crushers. Near the main building are situated the boiler-house, with ninety horsepower boilers, and a kiln with twelve retorts for revivifying the bone-black.

For the sake of convenience, the description of the apparatus will be given in eonnection with the process followed in the manufacture of sugar and sirup.

The caue is conveyed by means of a carrier fifty feet in length, to the first mill, a "Cuba" No. 4, manufactured by Geo. I. Squier, of Buftalo, N. Y., who kindly consented to the use of his rubber springs for our second mill, which was originally one of the rigid kiud.

After leaving the first mill the begasse is moistened with a spray of hot water, and is conveyed by means of an intervening apron to the second mill. By the nse of this second mill the sugar which is left in the begasse after passing through a single mill, as is pointed out in the report of our experiments, is practically all recovered.

The juice from the two mills is pumped together to the juice-tanks, which are placed at the top of the main building, and have a capacity of about 3,000 gallons. From here it is drawn to the defecators, where it is exactly neutralized with milk of lime in the cold, heated to the boiling-point, aud thoromghly skimmed. These defecators are mate of wood, lined with galvanized iron and supplied with copper coils for heating. Four of them have a capacity of 660 gallons each, and one of over 1,300 gallons. After settling, the juice is allowed to run into the evaporators, where it is concentrated to a density of $255^{\circ}$ Baum6. The evaporators are two in number, eight feet in diameter, mado of copper, and supplied with copper coils. From the ovaporators the Jifuor runs into settling-tanks, and next through bone-coal filters. The filters are four in number, 2 feet in diameter, and twelve feet high. The liquor is next drawn un into the vacuum-pan, where it is concentrated to melada. The crystallization of the sugar takes place in the vacuum-pan, and conld at once be run into the mixer and centrifugals. Owing to the fact that only one centrifugal has thus far been supplict, the strikes from the pan are usually run into rerstallizing wagons and placed in a warm room until the sugar can be "swung ont." There are fifty of these wagons having a capacity of 120 gallons each.

The quality of the sugar produced is unobjectionable in regard to taste and color. It grades as extra yellow "C," aud sells readily at the fuetory at $8 \frac{1}{2}$ cents per pound, in lots of five barrels. The molasses is of a dark color, but still is rich in cane sugar. It is stored up in barrels and will be kept until the cane is all harvested, when it will either be refined or worked over for a second yield of sugar.

The company raised 190 acres of eane, 8 acres of which is "Kansas Orange," about 40 acres "Early Orauge," and the rest "Early $\Lambda$ mber." I'rivate parties planted about 100 acres more, all of which was Early Amber, with the exception of one field of Larly Orange, containing $12 \frac{1}{2}$ acres.

The company began working up their Amber canes on September 21. An analysis of the juice was madr with the following result:

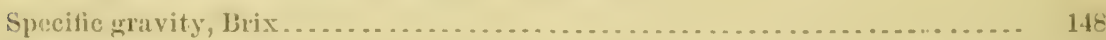

Cane sugar........................................... per cent.. 8.10

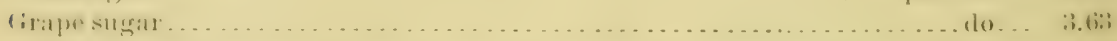

The best Amber cano of the company was grown ou sod ground, the field containing 50 acres. The composition of the juice of the field on Oetober 21 , was as follows :

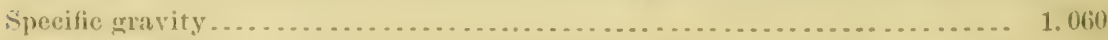

1 ':111. -

Grapo sugar.................................................... 
Owing to the lateness of the season, one continuous run was made, and the cane raisod by private parties was worked up with the company's cane, so that it will be impossible to give the yield per ton and acre before the close of the season's work.

One field of Early Orange, grown by Mr. J. G. Clark, has been harvested by itself ind the products kept separate. Of this field aud variety of cane, exact data can be given.

The composition of juice, October 24 , was as follows:

Specific gravity ................................... $1.070=16^{\circ} .3$ Brix.

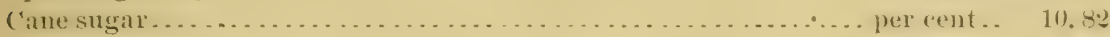

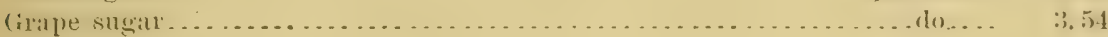

Number of acres in field, 1225.

Total amount of cane stripped and topperl.....................tons. . 156

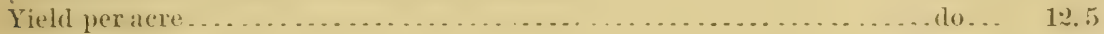

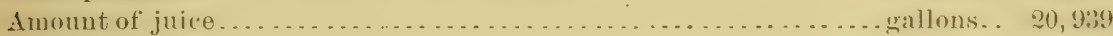

Wì eight .............................................. nounds... 185, 947

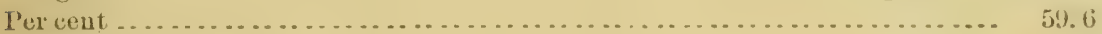

Weight of melada.................................... pounds. 25,920

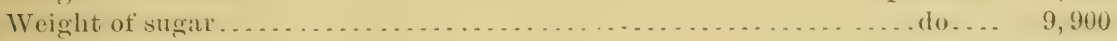

Weight of molasses........................................... 116,020

Quantity of molasses............................................... 1, 456

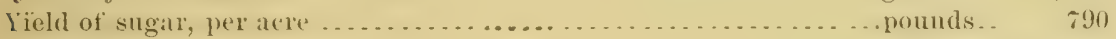

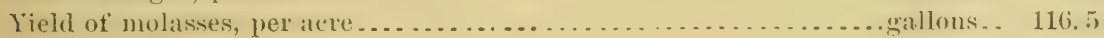

In this statement the amount of water added in moistening the begasse before passing the second mill has been deducted from the total amount of juice obtained.

The melada obtained from the Amber cane is fully as rich in sugar as that obtained from the Orange. The yield of sugar aud molasses, per acre, will bo lower for some of the fields of Amber, but for others it will be fully as high, and in a fer cases perhaps higher.

It is not more than fair to add that for this section of the conntry the season has been very unpropitious for the proper development of sorghim cane. This will be seen at a glance by comparing the analysis given here with those made in this locality last year and the year before, as given in our report. The necessary hot summer temperature for the production of a high percentage of sugar was ontirely winting. But on the whole, the sorghum sugar industry is to be congratulated, for this cold, wet season, as the flattering results which we are, nevertheless, obtaining here, will forever silence the claim that sugar can be made from sorghum ouly under the most favorable eireumstances.

Since the above account was reported to the Academy I have seen it publicly stated that this company has produced about 125,000 pounds of sugar and 20,500 gallons of molasses lluring the last season. 'They estimate the return at $\$ 75$ per acre.

Valuable statements have also been mate with less detail than those I have fully lairl before you, by Mr. Magmus Swenson, of the University of Wisconsin, for the vear 1889: Cant. R. Blakesley of the Faribault Refinery, Minnesota, for the year 18s1; Mr. .Tohn 13. Thomas, of the Crystal Ialie liefinery, Illinois, for the rear 1881; Mr. А. .J. Russell, Janesville, Wis.; all of which have heen submitted to me by the dearemy.

The following letter trom Mir. Hemry 'Taleott, presirlent of the Jefieresom Sugar Manufacturing Company, Ashtabula, Ohio, addressed to the 


\section{Depatement of Agriculture, I alse find in the appendix to the report}

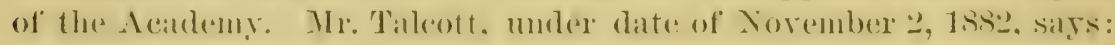

I have heen enteavoring to secure a practical method of protuciug the same results which they have obtained at the Rio Grande Company's works, where I have just been for myself-that our farmers could all adopt with small means, and make the indistry nuversal. I think mir company can show the world as complete sucess in about four weeks as the liin Grande have done, on a meh smaller and more simple scale. We are now crushing and hoiling from ten to fifteen tons of cane stalks daily: have been doing this for fuur weeks past ; our returns, in yield, are the same in substance an the Rio Gramle; but, unlike them, we lave had ten or fifteen good hard white frosts, some of them hard enongh to freeze ice on water thick as window-glass. Our eane was standing in the fields; we are yet cutting it. I had ten acres of it on my own fam. We see no ill efreets from it (the frost) in our work. We lave made just as good a yeld of juice; it makes just as good sirup and sugar, and all we have lost, as fir as we can cliscover, is the leaves for our cattle fodder. Mr. (4. C. Potts wished me to notify you of this fact on my returu home; also to send yon some samples of our work. We cook in open paus, by the Stewart process, only much more "perfect than he ever did his work (exeept in theory). F. C. Knight analyzed our mush sugar and finished sugar yesterday, in their refinery, and pronomeed it the purest and best sugar they ever saw. The sugar was our "second." This year's stock is still in owr hot-room graunlating slowly, for we lare not cook it dry in open pans, for we are so liable to seoreh it when near done, so we make time and warm room do part of the work. We shall not use our centrifugal until the elose of the month; shall then have from sixty to eighty thousand pounds of mush to work over. I shall make a complete and clear report of it to the department as I possibly can. I shall also visit the Champaign Works in Inlinois next week and eompare notes with them. I have an invitation to do se, and must see the botton of this industry so far as it is practically developer. Of eourse the vacum-pan and animal-bone filter make the refined sugar at onee; a specimen of it they sent me yesterday, and I inclose a little of it for you; but this expensive machinery, if it is more profitable, cannot bo made to come in general use. Our farmers must do this work as handy as they can make good butter and cheese, to get them into it in any great numbers. Onr faetory axe learning many of them to do the work, and sereral others are to-day making mush sugar at their own molasses factories, while we furnish them solution $B$, and do their centrifugal work. I will send a little sample of sugar we purged yesterday for Mr. P. A. Upp, of Edgerton, Williams Comty, Ohio, who made it miter our directions, and then brought to the finctory to see our works, and with his own ejes see finished sugar of his own make. I guess he was as well pleased with the result as auy fond mother conld well be with her first born. He returned home with his sugar, and said he shonla now go shonting among his own people, for he had accomplished well what his people all saicl was an impossibility.

\section{'The committee of the Acalemy state in this comnection:}

It is from the States of New Jersey and Inlinois that we are able to cite examples of success on so large a seale and attended with sneh an meruivenl result as fairly puts to rest any doubts as to the production of sngar on a great seale in a northern elimate with a commercial profit.

Hence it is that I have quoted the reports from Rio Gramb and Champaign.

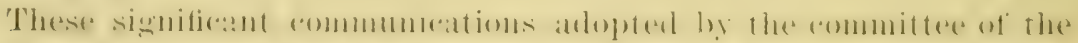

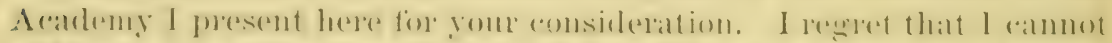

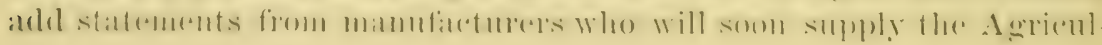


tural Department with reports corering the following points submitrent to them in my circular of Jume 6,1882 , viz:

1. An aceurate acconint of the number of acres of sorghum brough: to the mill; the number of tons of cane manufactured; the yield of sorghum per aere; the mollo of fertilizing; the time of planting; the time repuired for maturing the plant; the value of the crop as food for cattle, after the juice has been expressed.

2 . The amomit of sugan mannfactured; the amount yielded per for of cane; the quality of the sugar; the amount of sirup) manufactured; the process of manufacturing; the machinery used; the success of the evapolator, the valum-pan, and the centrilugal in the rorli of manufacturing:

3. The number of liands employed in the mill; the cost of fuel; the cost of marhinery; the wages paid for labor; the price of sorghum at the mill, if not raised by the manufacturer.

The replies I shall receive to this circular will be published as soor as they can be properly arranger, and I rluubt not they will coutain s large amount of valuable and interesting and accurate informatiou.

It will, I donlet not, be gratifying to ascertain the extent of the sorghmm industry in the country; and I have endeavored to arrive at this as far as possible by means of circular letter's adelresser to correspondents in crery connty in the Union. I have receiven imperfect report: from the following States, and I sulmit them in this comnection, not as a complete retmrn, but omly as indicating to a cortain degree the extent

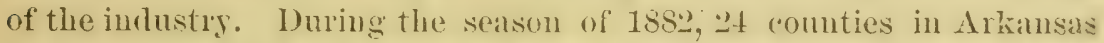
have prodnced 720,500 gallows of sirup and no sugar, as returned; 12 counties in Alabana have produced 520,125 gallons of molasses and mo sugar; à comties in Dakota have producel 139,615 gallous of molassas and no sugar; 4'2 comties in Georgia have produced 565, (12:3 gallons of molasses and 5, 150 pounds of sugar; 3.5 counties in Indiana have produced 618,410 gallons of molasses anel no sugar; 32 counties in Illinois have produced $6(30,633,3$ gallons of molasses aud 13,200 pounds of sugar ; 38 connties in lowa have produced 491,949 gallons of molasses aurl 731 pounds of sugar; 32 counties in Kansas have produced 950,047 gallons of molasses and 100 pounds of sugar; 3. counties in Kentuck have produced $5.3,700$ gallons of molasses and no sugar: 10 connties in Louisiana have produced $\$ 1, \$ 00$ gallous of molasses and no sugar ; 37 comnties in Missomri have prolucerl $1,405,3.50$ gallons of molasses am 2,400 pounds of sugar; 22 counties in Minnesota have produced $206,-1,3$ gallons of molasses and 100 pounds of sugar; 16 comties in Michigan have produced 46,50:3 gallons of molasses and no sugar; 15 counties in Mississippi have produced 5:30,100 gallons of molasses and 2,200 poumbs of sugar; one county in Maryland has produced 1,200 gallons of numlasses and no sugar; 2 counties in NeW Jersey have produced 4", (mm gallons of molasses and 319,000 pounds of sugal: s counties in New Tork have producel 101,261 gallons of molasses and !(0,1;0 pounds of 7248 


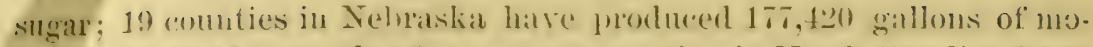

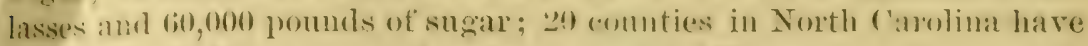

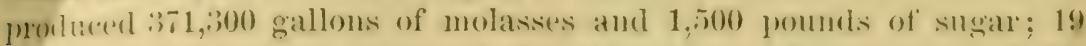

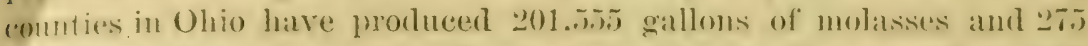

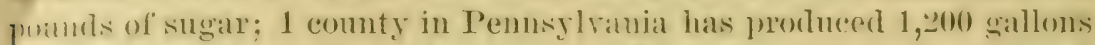
of molasses and no sugar; 6 connties in Sonth Carolina have produced

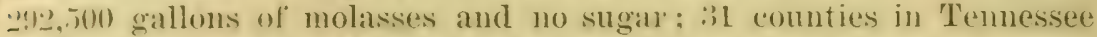
hare produced $2,12.2,700$ gallons of molasses and jo poumds of sugar; 47 counties in Texas have produced 9.5,9) gollons of molasses and soo pounds of sugar; 7 comuties in Utah have produced 67,450 gallons of molasses and 10,000 pounds of sugar; 20) ('ounties in Virginia hare prodnced 132,571 gallons of molasses and no sugar: 1:) comuties in West Tirginia have produced 379,200 gallons of molasses and 12,5 poumls of

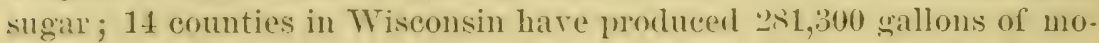
lasses and 5,000 pounds of sugar. In all, 12.898 .001 gallons of molasses and 509,731 pounds of sngar.

You will observe that this is but a small number of the counties in the States enumerated, and that undoubtedly some of the hest sugarproducing counties have been omitted.

The census of 18 sol thus far contains acrulate statisties from only four States, viz:

\begin{tabular}{|c|c|c|c|c|}
\hline & States. & Acres. & Sugar. & Molasses. \\
\hline $\begin{array}{l}\text { Kansas ......... } \\
\text { Louisiana ..... } \\
\text { Mlinmestat } \\
\text { South Carolina }\end{array}$ & ….................... & $\begin{array}{r}20,643 \\
1,015 \\
7,221 \\
7,660\end{array}$ & $\begin{array}{r}\text { I'nuendss. } \\
18,060 \\
4,000 \\
8,4.57 \\
8,225\end{array}$ & $\begin{array}{r}\text { Gallons. } \\
1,414,404 \\
38,736 \\
345,556 \\
276,046\end{array}$ \\
\hline
\end{tabular}

And now, gentlemen :

The finther derelopment of this business depends on the judgment and wislom of those who are engaged in it. There seem to be several methols by which the desired result at be whtainnd, the choice of which is to be governed hy soil. climate, and atmospherice influences. 'The condition of the (erep) depents, of comrse, on the state of the soil in which it is grown. 'The conversion of the erop intesugar depends mon the skill with whieh it is harvested and sulyjected to the varions methods

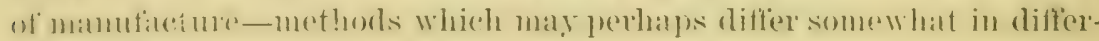
ent localities.

I am informed by one of the most intelligent investimators that the

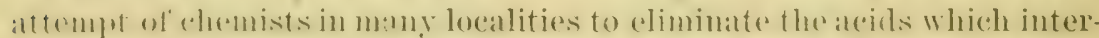

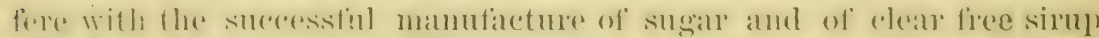

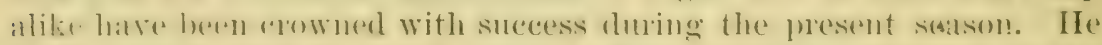

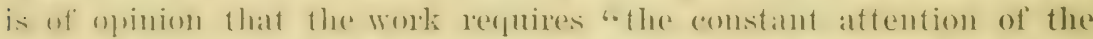

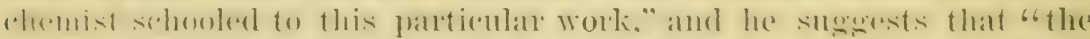

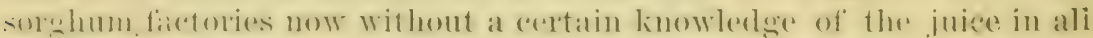
its stages will fail to probure sugal in any certain quatutitios." This ob)- 
server's views of the prospect of the business in Kansas, Minnesota, Wisconsin, and Illinois are encouraging.

I have of comsespoken, gentlemen, not as an expert in this matter, but as an olserver whose ofticial duty it is to encourage every branch of agriculture in our comutry, by wise co-operation with those who are engaged in the work of tilling the soil.

The fact that sugar can be made fiom sorghum has been proved. That it can be profitably mark Profensors Weher and seoville have demonstrated, and have so declared to this association with their figures before them. That there is a market for the protuct no man doubts. Whether it is a miversal crop or not, time and experience alone can prove. When I asked Professor Weber, yesterday, "What are the ob. stacles P'rofessor Goessmann found in Missidchusetts which render sorghum sugar-making there impracticable?" his reply was: "Shortness of the season, danger of early frosts, and an incomplete development of the cane." Who ean say, as yet, that this crop will talie its place among the special crops of our extreme Northern and Eastern States, or will occupy the place now filled by the sugar cane of the South? Tor is this important. Lilie all other agricultural products, the profit of sorghum depends on locality, soil, elimate, and the commercial status of the cultivator as regards the ownership of his lamd; whether he possesses a plantation of thrusands of acres or at small farm; whether he sets up his own stagur mill and runs a sugar plantation or depends upon a neighboring factory for his market of the crop from his few acres. We have a right to expect that it will find its plare, as every other crop has done, and will be aceepted in its proper sphere either for the domestic supply of molasses when convenient and economian or for conversion into sugar where circumstances are favorable. It took mauy jears for the great cotton and woolen and inon industries to establish themselves and oceny the market, but their founders made their goods, foumd their market, and pocketed their profits. They worked with perseverance, economy, and great ingenuity and skill. Lou can follow their example. 








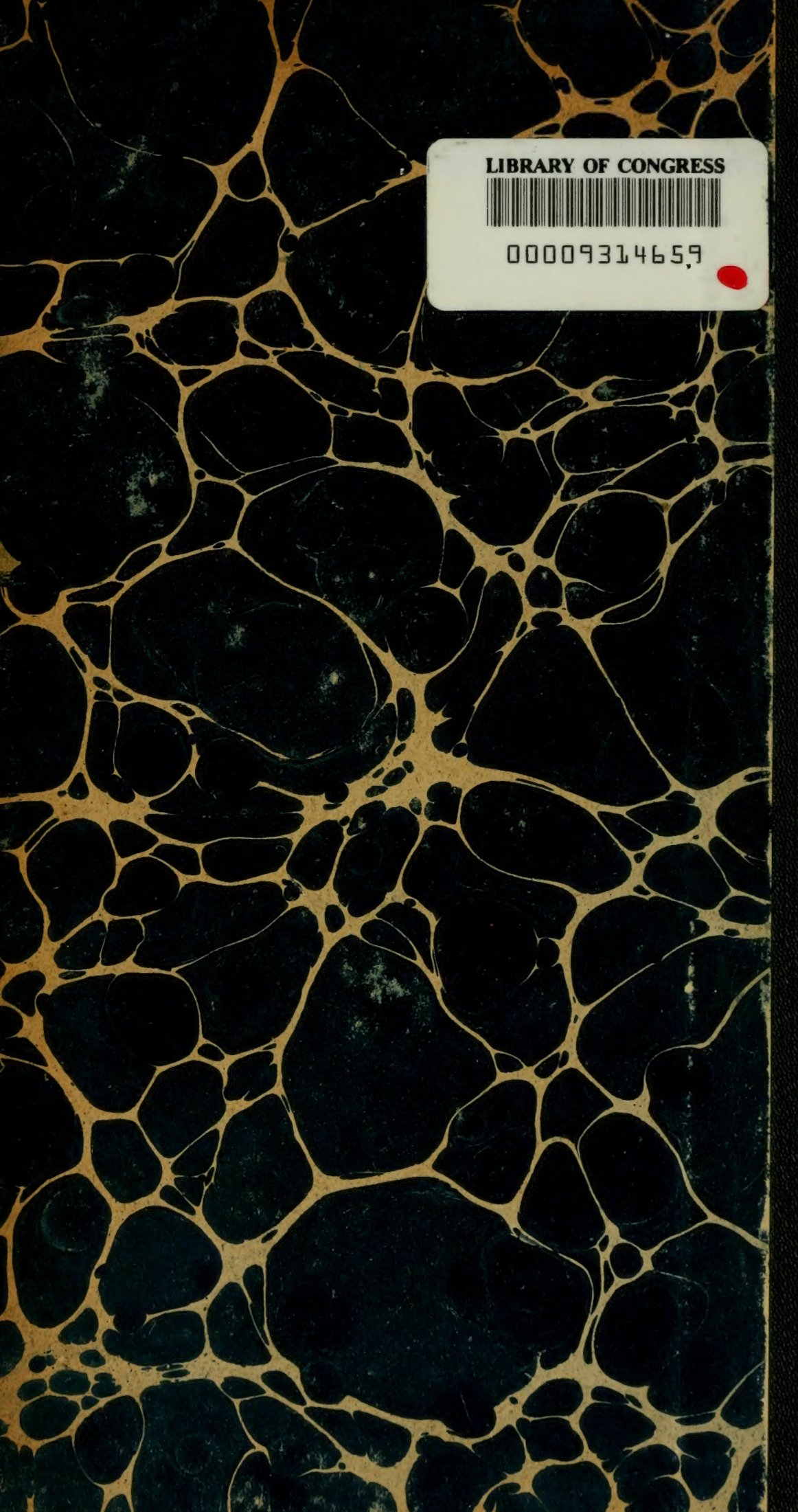

